now so carefully studied. A coming Newton will discover the laws of these changes. Those laws, when applied to chemistry, may exhibit peculiarities, but these will certainly be mere varia tions on the grand harmonious theme which reigns in Nature. The discovery of the laws which produce this harmony in chemical evoiutions will on'y be possible, it seems to me, under the banner of Newtonian dynamics which has so long waved over the domains of mechanics, astronomy, and physics. In calling chemists to take their stand under its peaceful and catholic shadow, I imagine that I am aiding in establishing that scientific union which the managers of the Royal Institution wish to effect, who have shown their desire to do so by the flattering invitation which has given me--a Russian-the opportunity of laying before the countrymen of Newton an attempt to apply to chemistry one of his immortal principles.

\section{BABYLONIAN ASTRONOMY.}

\section{IV.}

THE nightly motion of the stars from east to west appears to have been the only one known to the Babylonian astronomers. The inclination of the equator on the ecliptic brought, however, a few of the austral stars over the horizon at certain times of the year for a short period, and in a few cases, as in that of the star Sukutu (Sirius), these stars were used to determine certain periods or festivals. The complicated motion of the planets never was known to them, and the planets were accordingly regarded as evil spirits which disturbed the harmony of Nature. A similar view is taken in the Zend-Avesta. After a cosmical year of 360,000 ordinary years, the series of heavenly and consequently terrestrial events was to begin again.

While the Semitic religion had emerged from tribal monotheism, the Alkadians followed a sect professing Mazdeism-that is, a religion admitting two principles, one good and one bad; but they thought that, as the 'good gods would not hurt them, it was wise to propitiate the bad ones, and propitiation easily led to worship. That is how the seven planets, the disturbers of heavenly harmony, became their chief deities. For the same reason all disturbing causes, apparent or real, were subjects of their special attention, pestilence, thunder, comets, \&c. Eclipses (which they could not predict) were at first also of bad omen, but by a curious reversion they became happy signs.

The ignorance of the Babylonians with regard to astronomy might have been gathered from the statements of classical authors, if they had been examined with an unprejudiced mind. Diodorus Siculus says positively that their notions about astro. nomy, fixed at an early date, nevcr changed, and that they could not predict the solar eclipses. We also know from a fragment of Berosus, preserved by Vitruvius, that the Babylonians believed the moon to be a globe half incandescent and half dark, the lunar phases and eclipses being produced by its own motion. The errors and contradictions of the Greek and Latin authors, which misled us also, came from the fact that they borrowed their information from the Alexandrian astronomers, who, they thought, derived their science from Babylon. This was true, indeed, but only to a very small extent, as we shall see.

When, after the conquest of Alexander, the Greeks established themselves in Babylon, they imported with them all their scientific knowledge. The Babylonians, who had to learn Greek, soon discovered the accuracy of their new masters in science, and, exactly as did the Chinese astronomers after the settlement of the Jesuits in China, adopted the discoveries of the West.

This is put beyond doubt by the tablets of this period, the Seleucidian, which give tables of the motions of the moon and planets, and mention solar and lunar eclipses without any omens. The Seleucidian astronomers, wishing to use the older observations, made search for old records and tabulated them; these tablets are of the highest interest from the astronomical point of view. The British Museum possesses, for instance, a tablet, written 100 years B.C., giving the list of nineteen lunar cycles of eighteen years-that is, a table combining the Metonic cycle with the saros. This saros, or cycle of the lunar eclipses, must have been discovered after the settlement of the Greeks; it was called the "king" (sar in Babylonian, hence saros in Greek) just as the Metonic cycle was called "golden."

The first care of these astronomical innovators was, no doubt,

Abstract of the fourth lecture delivered by Mr. G. Bertin at the British Museum. Continued from p. 285 . to reform the very defective calendar of former times. They also divided the ecliptic into twelve parts, corresponding to the months, and chose twelve cuneiform signs to represent in their tablets the twelve zodiacal constellations. They then devised the GræcoBabylonian calendar, whence was derived the Jewish one of the time of the Maccabees.

This reform was not made, however, without causing a certain confusion in the star nomenclature, and even in the calendar itself; for, as the older Babylonians used to connect the various parts of the year with the stars or constellations according to their acronic rising, there was a certain hesitation in the choice made by the reformers. Probably this was what caused the parallel use of two calendars, one beginning with Nisan and the other with Tisrit. This hesitation has also left traces in the signs chosen to designate the zodiacal constellations; for instance, the sign representing the month Tisrit in older Babylonian was used to represent the constellation connected with the month Nisan.

It was from this new focus of astronomical science that the Alexandrian astronomers borrowed much of their information. Unfortunately, the old Babylonian superstitions had a most injurious influence on the rising Alexandrian astronomy. Jewish, Syrian, and Babylonian emigrants, fleeing from the Seleucidian tyranny, flocked to Egypt, bringing with them their superstitions and love for allegories. The Alexandrian astronomers accepted with the Babylonian nomenclature all the ideas of influences attributed to planets and stars, and, being able to predict conjunctions, tried to predict events supposed to be due to star influences. Astrology was then born, for astrology, it must be remembered, requires an accurate knowledge of the motions of stars and planets.

In conclusion, it may be said that we owe very little to the old Babylonian astronomers, and if the astronomical work of Berosus h: dd been preserved, it would have given no scientific information, but only long lists of omens drawn from the rising and conjunctions of stars and planets, and also from their colour and other accidental aspects. The loss of such a work is not much to be regretted.

\section{BOOKS, PAMPHLETS, and SERIALS RECEIVED.}

Annuario dell' Instituto Cartografico Italiano, I88f (Roma).-Algerian Hints for Tourists: C. E. Flower (Stanford).-Mason Science College, Birmingham; Syllabus of Day Classes, Session r889-90.-The Visitation of Pallas's Sand-Grouse to Scotland in r888: Rev. H. R. Macpherson (Porter)-Quarterly Journal of Microscopical Science, July (Churchill). Madras Journal of Literature and Science for the Session 1888-89 (Madras). -Journal of the Anthropological Irstitute, August (Trübner).-Journal of the Chemical Society, August (Gurney and Jackson). - Archives Italiennes de Biologie, tome xii., fasc. I, 2 ('Turin, Loescher).

\section{CONTENTS}

Empirical Logic. By James Sully . . . . . . 337

Remsen's "Inorganic Chemistry" ..... 333

The Middle Lias of Northamptonshire ... . 34I

Our Book Shelf :-

Cundill: "A Dictionary of Explosives" . . . . . 34I

Thwaite: "Gaseous Fuel" . . . . . . 342

Casey : "A Treatise on Spherical Trigonometry, and its Application to Geodesy and Astronomy" . . . 342

Letters to the Editor:-

Coronæ round a Light produced by a Peculiar Struc. ture in the Eye.-James C. McConnel.

Use or Abuse of Empirical Formulæ, and of Differentiation, by Chemists.--Spencer Pickering Photographic Star-gauging. (Illustrated.) By A. M. Clerke

Two American Institutions. By J. Taylor Kay The Meeting of the British Association at Newcastle-on.Tyne

The New Buildings of the Sorbonne . . . . . . 34

Notes . . . . . . . . . . . 350

Astronomical Phenomena for the Week 1889 August II-I7 . . . . . . . . . . . . . 352 Geographical Notes . . . . . . . . . . 353

An Attempt to apply to Chemistry one of the Principles of Newton's Natural Philosophy. By Prof. D. Mendeleeff.

Babylonian Astronomy IV By G Bertin *. 35 Books, Pamphlets, and Serials Received ... 360 